\title{
The influence of language learner's Buddhist background on non-native written language processing
}

Liubov V. Darzhinova

The Education University of Hong Kong, People's Republic of China

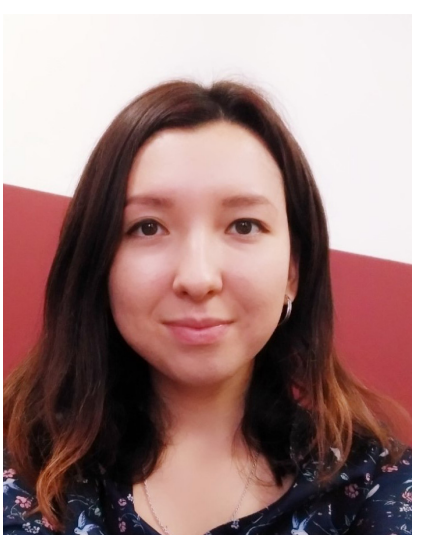

In today's digitalized world, discovering approaches to enhance written language processing is crucial for successful non-native language acquisition. Whereas psycholinguistic literature suggests that background knowledge generally facilitates written language processing, hardly anything is known about whether religious affiliation as a part of language learner's background affects non-native written language processing.

Consequently, the current paper addresses the gap by conducting a small-scale webbased self-paced reading study. It explores whether English language learners with Buddhist background process the Buddhist-related and religiously neutral texts similarly to those with the same proficiency level but with no religious affiliation. Thus, the experiment involved 20 Buddhist and non-religious learners of English from Russia's regions of Kalmykia, Tuva, and Buryatia.

The results of the experiment suggest that the Buddhist background of English language learners contributes to faster processing and better recall of Buddhist-related texts in the target language. The paper argues for the need to supply written materials related to religion in a target language with notes and glossaries in order to hasten processing and improve recall in nonreligious language learners.

Keywords: language learner; Buddhism; Buddhist background; non-native language; written language processing; reading; recall; reading time; idea unit

DARZHINOVA, Liubov Vladimirovna, PhD candidate, Department of Linguistics and Modern Language Studies, PhD fellow, Centre for Research on Linguistics and Language Studies, The Education University of Hong Kong, 10 Lo Ping Rd, Tai Po, New Territories, Hong Kong SAR. Tel.: +001 (852) 2948 7546. Email: liubov@s.eduhk.hk

Даржинова Любовь Владимировна - докторант кафедры лингвистики и исследований современных языков, научный сотрудник Центра лингвистических исследований и изучения языка Университета образования Гонконга САР Китая. Адрес: 10 Lo Ping Rd, Tai Po, New Territories, Hong Kong SAR. Тел.: +001 (852) 29487546. Эл. адрес: liubov@s.eduhk.hk 


\title{
Влияние буддийского мировоззрения обучающегося на обработку неродной письменной речи
}

\author{
Любовь В. Даржинова \\ Университет образования Гонконга, Китайская Народная Республика
}

\begin{abstract}
В сегодняшнем цифровом мире поиск подходов к совершенствованию обработки письменной речи имеет решающее значение для успешного освоения неродного языка. В то время как психолингвистическая литература предполагает, что фоновые знания обычно облегчают обработку письменной речи, мало известно о том, влияет ли религиозное мировоззрение, как часть знаний обучающегося, на обработку неродной письменной речи.

В настоящей статье выявленный пробел устраняется путем проведения небольшого Интернет-эксперимента в форме чтения с регулировкой скорости. Целью эксперимента является ответ на вопрос о том, аналогична ли обработка текста, связанного с буддизмом, а также религиозно нейтрального текста у буддистов со средним уровнем владения английским и у нерелигиозных с аналогичным уровнем владения. Так, в эксперименте приняли участие 20 буддийских и нерелигиозных студентов, изучающих английский язык, из российских регионов - Калмыкия, Тува и Бурятия.

Результаты эксперимента показали, что буддийское мировоззрение изучающих английский язык способствует более быстрой обработке и лучшему запоминанию связанных с буддизмом текстов на целевом языке. В статье также утверждается, что письменные материалы на изучаемом языке, касающиеся религии, необходимо обеспечить примечаниями и глоссариями для ускорения их обработки и улучшения запоминания у нерелигиозных читателей.
\end{abstract}

Ключевые слова: обучающийся; буддизм; будийское мировоззрение; неродной язык; обработка письменной речи; чтение; извлечение из памяти; время чтения; идейная единица

\section{Introduction}

The massive information flow, being the result of digitalization, has been instigating fragmentary understanding of written language and poor consolidation of the received information (cf. Delgado, Salmerón, 2021; Kekeeva, Darzhinova, Abdiraimova, 2020).

In view of the situation, finding approaches to accelerate reading instruction and teach efficient processing and comprehension strategies is of paramount importance for the fields of language pedagogy and language acquisition, respectively. The more words and concepts readers hold prior to be subjected to a certain input, the better they can read and understand it, as well as make some inferences to clarify the putative uncertainty. Hence, one of the feasible ways to augment written language processing and comprehension in students and language learners is to help them activate and apply previously learned information and experiences.

By conducting a mixed-method study, the paper initiates the literature review, with the following research question: What are the ideas presented in the literature about the background of language learners in a non-native language processing? Besides, the paper presents the small-scale web-based self-paced reading experiment conducted in December 2020 among intermediate English learners with the Buddhist background (Group 1) and intermediate English learners with no religious affiliation (Group 2). Next, the paper furnishes 
the results of both groups in the form of overall reading times (RTs) measured in milliseconds per each text as well as cumulative recall summary scores. Thus, the experiment aimed at finding out whether or not Buddhist religious background, as a part of language learner's prior knowledge, is a driving force behind written input understanding in a target language.

\section{Background knowledge in written language processing}

Written language processing constitutes the three-fold cognitive process, namely word recognition, parsing, and semantic integration. At the stage of word recognition, lexical information of individual words, e. g., meanings, morphological structures, lexical associations, becomes available (Carreiras et al., 2014). Parsing of an input is then built on the account of the activated lexical information, morphosyntactic cues, e. g., word order and case marking, and reader's syntactic knowledge (Henry, 2015). In this vein, the sentence plausibility judgment study of Russian-English bilinguals suggested that in the temporal flow, there is no significant difference between word recognition, i.e., semantic processing, and parsing, i. e., syntactic processing (Navracsics, Darzhinova, 2020).

At the semantic integration (final stage), mental representations of the sentence meaning are assembled on the basis of the information derived from the input and an individual's preparedness (Ferreira, Chantavarin, 2018). As seen from Figure 1, the written sentence may be split into given and new information. The given information interacts with the knowledge and experiences obtained before, as well as with the earlier received context to form the semantic representation. Concurrently, this representation is utilized to predict the forthcoming information, or initiate the state of preparedness in the form of a set of semantic characteristics, which may turn out to be enough for pinpointing a specific lexical candidate.

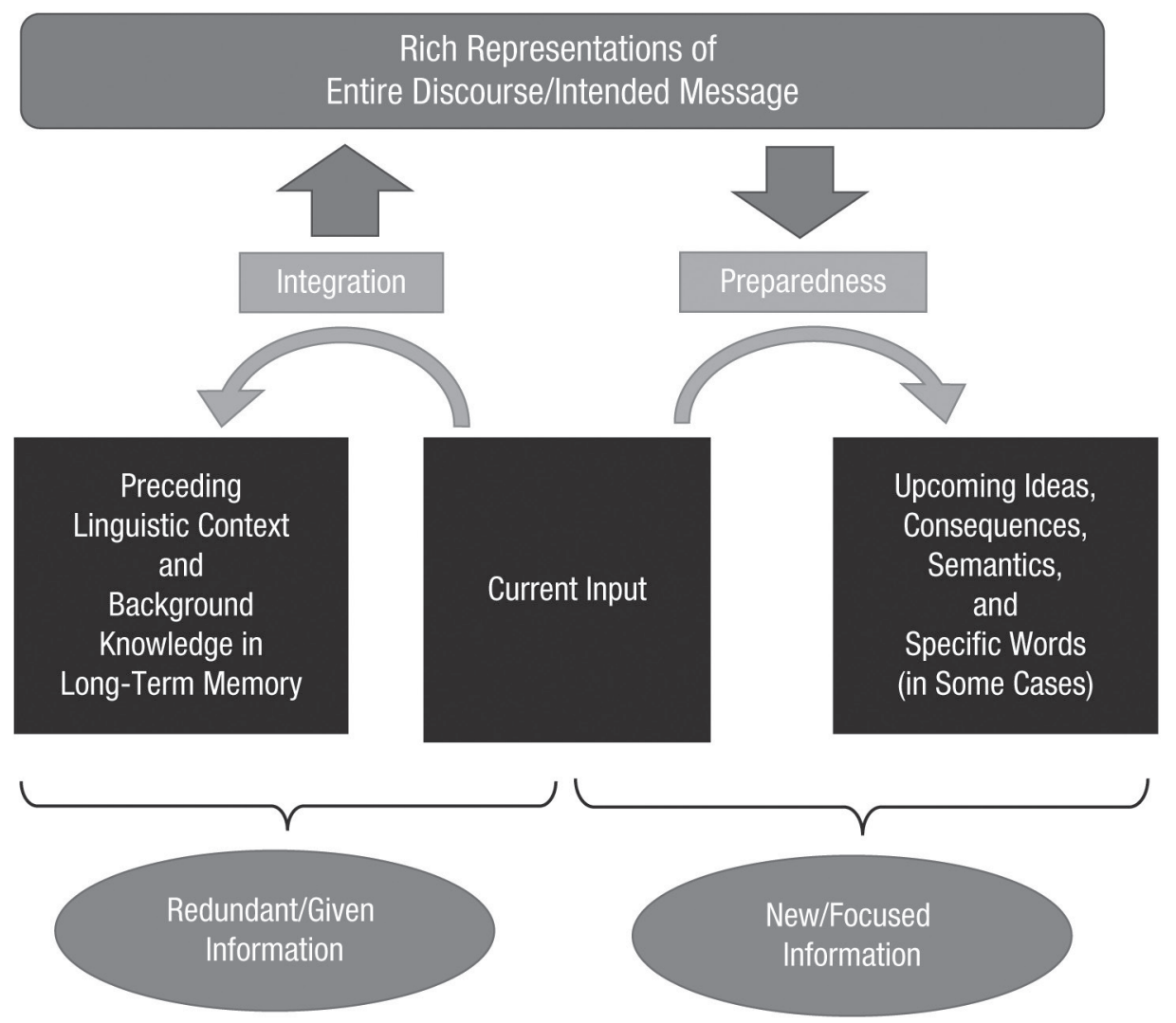

Figure 1. The interface of preceding context, prior knowledge, and experiences in written language processing for "preparedness", i. e., predicting forthcoming information, adapted from Ferreira \& Chantavarin (2018).

The literature has been labeling such preparedness diversely over the years, for instance, expectation (e.g., Smith, Levy, 2013), schema (e. g., An, 2013; Rumelhart, 1980), forward-inferencing (e. g., Graesser, Singer, Trabasso, 1994; Murray, Klin, Myers, 1993), knowledge activation and integration (e. g., Long, Lea, 2005), and prediction (e. g., Kuperberg, Jaeger, 2016; Dell, Chang, 2014), inter alia. 
Early research (Rumelhart, 1980) proposed the Schema Theory suggesting that written language processing is an interface between the reader's background knowledge and the actual reading material (Figure 2). In essence, schemata labels reader's background knowledge and past experiences, which make inferences from the events described in written language input. Since schemata signify a reader's experience and prior knowledge, they can be culturally specific.

\section{BIRDS}

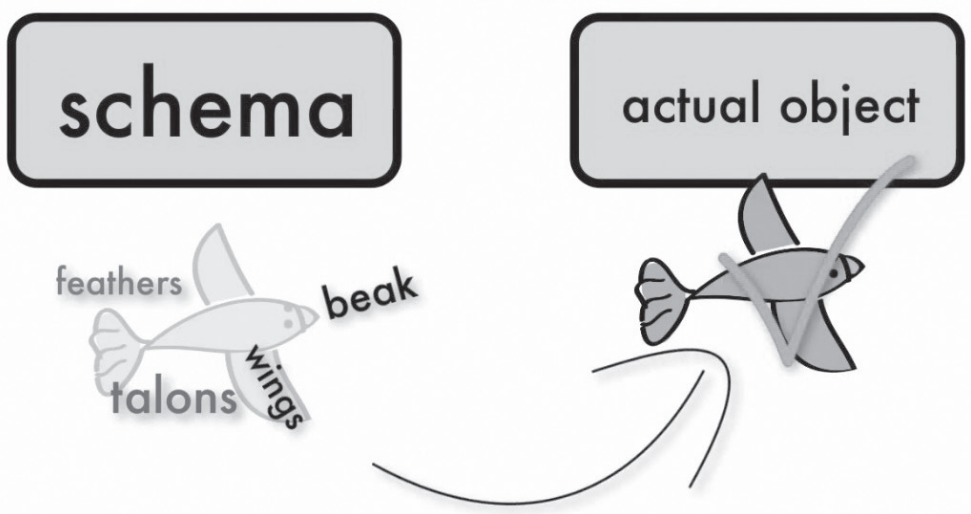

Figure 2. The illustration of the cognitive pattern, or schema "birds" used as the means to compare the input against prior information, adapted ${ }^{1}$.

In the same framework, An (An, 2013) illustrated written language processing as a two-fold path, from bottom to the top and from the top to the bottom, known as the bottom-up and top-down approaches, respectively. Bottom-up processing is stimulated by certain data from the written language material, while top-down launches in conjunction with general data to confirm some expectations. Both processes happen simultaneously and interactively and are guided by different types of schemata (Figure 3), organized in a tiered fashion, with the broadest at the top-down level to the most particular at the bottom-up.

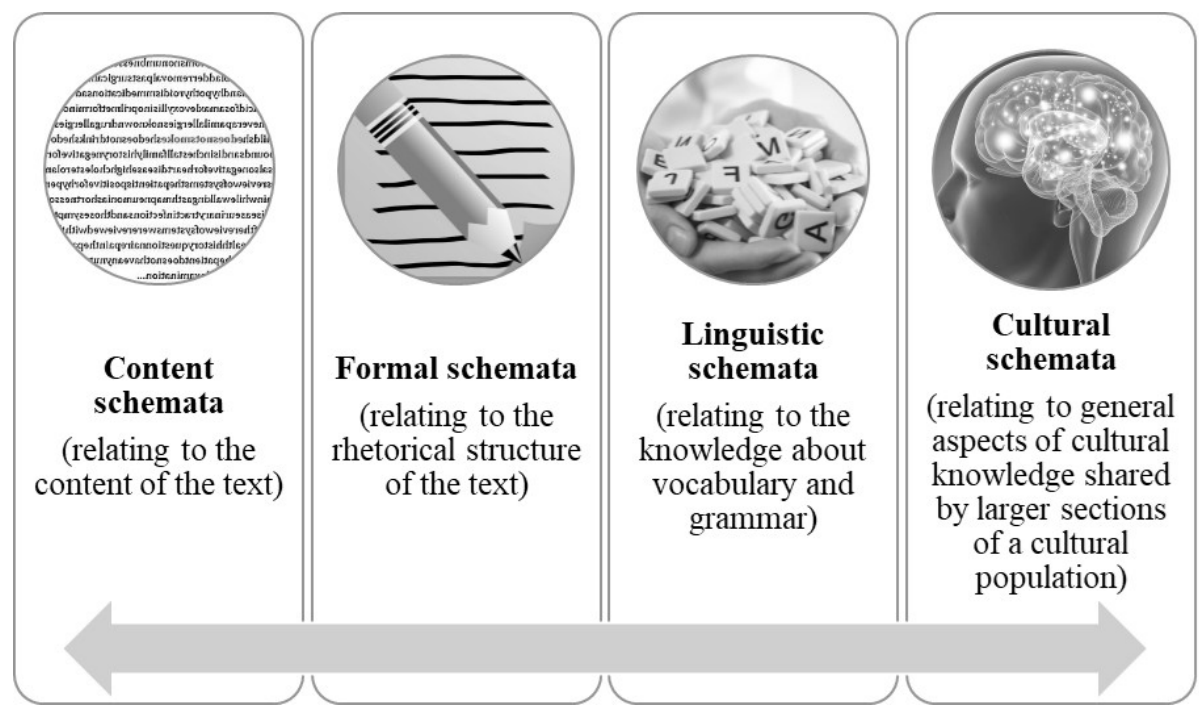

Figure 3. Types of schemata from An (2013), elaborated by the author.

Murray, Klin, and Myers (Murray, Klin, Myers, 1993) instituted an on-line naming time task to test whether English-speaking readers make inferences while reading different text types. Experiment 1 presented the extensive passages comprised of the so-called causal coherence break, i. e., prior information related to the consequently inferred scenario. Experiment 2 compared reading behaviors for shorter versions of passages

${ }^{1}$ Tinoco-Giraldo, H. (2016, May 17). Schema Theory and Cognitive Load Theory [Video file]. Retrieved from https:// www.youtube.com/watch?v=R9uOgYneh8g 
НОВЫЕ ИССЛЕДОВАНИЯ ТУВЫ

www.nit.tuva.asia

from Experiment 1 but ending with actions of predictable consequence (and devoid of coherence breaks) and the same passages but with coherence breaks (and no predictable consequence). The dependent variable for both experiments was the response latency time (naming time) for keywords from targeted inferences. The major finding for Experiment 1 was that response latency for prediction items is shorter than for control items, suggesting that passages with the focus on the targeted inference and the causal coherence break prompt readers to draw forward inferences. With regard to Experiment 2, naming times were shorter for the predictable consequence passages than the passages containing causal coherence breaks. In sum, the study argues for the idea that readers draw forward inference even from two-sentence passages, and the passage length is not crucial. What is more, causal coherence break robustly triggers readers to forward-inferencing, but its presence in the text is not essential for drawing inferences.

Graesser, Singer, and Trabasso (Graesser, Singer, Trabasso, 1994) proposed the so-called Constructionist Theory of Narrative Text Comprehension, according to which readers constantly pursue meaning of what is written, as there is no input that is completely clear, by applying their own knowledge in order to construct and interpret incoming information. The researchers differentiated between the two inferencing processes that underlie the facilitation of written language processing. Thus, a bulk of inferences is usually drawn while reading at the local level (e. g., understanding of that "her" in "Kate nailed her exams" corresponds to Kate) and the global level (e. g., understanding of the whole plot of a story). Nevertheless, readers' interpretations do not anticipate a thorough and coherent illustration of the actually described scenario, but rather depict their biased representation that is meaningful to them.

Long and Lea (Long, Lea, 2005) suggested that once readers process some written material, they implicitly integrate their knowledge, experiences, and contextual information with it to either filter out the information that does not make sense or match these with the material. The authors pointed out that this process is not only useful for maintaining general understanding about the read material, but also facilitates the disambiguation of uncertain texts or sentences, formulates reading predictions and creates some tacit links between the conveyed ideas. When the written material is inconsistent with what readers have in their background, rereading as well as strategic memory retrieval typically take place and therefore would result in the inflation of total RTs, i. e., the sum of all fixations per sentence or word-chunks in an eye-tracking experiment or buttonpresses in a self-paced reading experiment.

Concerning RTs, Smith and Levy (Smith, Levy, 2013) reported that the complex integration process, which contributes to understanding of a written stimulus, functions incrementally, that is, on a word-by-word basis. In other words, readers constantly construct and revise their expectations about the incoming units based on the available context and their prior knowledge. From a quantitative point of view, this means the processing speed displayed for the incoming word is "an inverse logarithmic function of its contextual predictability yielding graded effects" (Veldre, Andrews, 2018: 12). In psycholinguistics, this processing speed is a measure of processing impediment, which is expressed in response latency time per word, chunk of words, or a region as in self-paced reading tasks, and RTs in eye-tracking research (typically, in milliseconds in both cases). Overall, real-time written language processing in human parsers is led by their previous knowledge, so that the stronger their expectations for each read chunk, the less difficult they are incorporated into the contextual framework of the written material.

Dell and Chang (Dell, Chang, 2014) put forward the socalled P-chain, the psycholinguistic framework encompassing all three psycholinguistic domains- comprehension, production, and acquisition. To illustrate the proposed framework (Figure 4), the researchers portrayed interlinks between the

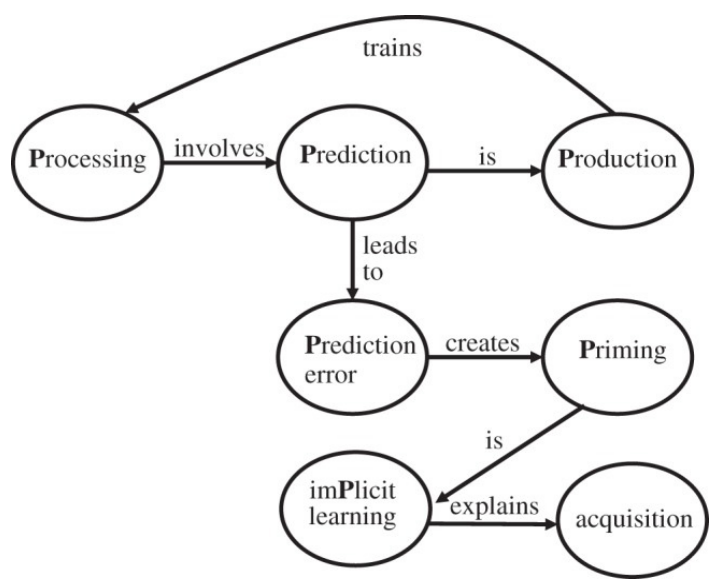

Figure 4. The P-chain adapted from Dell and Chang (2014). phenomena in review as a chain routing from language processing and post-processing, that is comprehension, over five P-concepts at most, including notably, production, to language acquisition in the end. Through the same illustration, the chain's loop goes from production back to processing, thus displaying the prominence of language production. One of the central P-concepts in the framework is prediction implying reader's expectations regarding impending information, e. g., anticipation of the semantic properties of upcoming words. 
More lately, Kuperberg and Jaeger (Kuperberg, Jaeger, 2016) examined potential ways, in which prediction had been discussed in the literature. The authors claimed that nominally prediction is the process of how human parsers apply high-level information through their contextual representation to probabilistically surmise the impending information. This means that several possible readings are triggered simultaneously, which may be given different plausibility power at any time point. Further, they suggested that even prior to encountering a single word further in written language processing, the context wields its impact in a bottom-up manner within the initiation of assumptions concerning the subsequent information via syntactic, semantic and, possibly, lexical constraints. In other words, contextual predictability of a word is likely to be the predictor of how fast and precise that word will be understood. In sum, the real-world knowledge about concepts and potential scenarios holds the key place in language processing.

Thus, taking into account the same underlying meaning in the reviewed labels ("preparedness", "schema", "expectation", "forward-inferencing", "prediction", and "knowledge activation and integration"), it seems that they all imply the same phenomenon in one way or another. For convenience, the paper will employ the overarching term "background knowledge" to refer information and experiences that are pertinent to the processed written stimulus. Based on the reviewed literature, the linkage between reader's background knowledge and written language processing has been recognized for over forty years. One strand of research (e. g., Long, Lea, 2005) indicates that the reader's competence to structure the incoming material and link it with the already held knowledge is a concomitant part of written input interpretation. Other studies (e. g., Kuperberg, Jaeger, 2016) claim an efficient understanding of written language obliges readers to correlate the inbound material with their prior knowledge and rely on it correspondingly.

While the literature clearly argues for the facilitating effect of a prior knowledge on written language processing, there is not much evidence for its effect on non-native reading, namely L2. The review above lacks research on whether religious affiliation, being a part of language learner's background, is a driving force behind L2 reading. In this regard, the existing conclusions on the broad issue of the role of background in reading are non-exhaustive. At the same time, having spotted one study related to the phenomenon, this paper will further examine it by pursuing to establish whether or not there is the clear interrelationship among religious background and L2 written language processing.

Markham (Markham, 2001) investigated into how religious background knowledge influences processing of a religion-specific material in students. The author particularly scrutinized how Buddhist, Muslim as well as religiously neutral student groups processed the available written language supplementation in watching religious videos in a L2 English medium. The number of idea units produced by each student in written summaries was the reliant measure in the study. The results demonstrated that earlier knowledge about the relevant religions impacted the first two groups in a way that, e. g., the Buddhist group achieved a higher unit score upon processing the Buddhist passage than the Muslim and religiously neutral counterparts. Similarly, the Muslim group did better than the other groups at the processing of written supplementation of the Islamrelated video. The study, however, affords evidence only for the facilitating effect of religious background on the processing of spiritually related video material with integrated captions and not standalone written language stimuli.

\section{The web-based experiment}

\section{Participants}

Twenty adult learners of English $\left(M_{\text {age }}=21.65\right)$ took part in the experiment. The snowball technique (Nilsson, 2015) was utilized for participant sampling. To balance the sample size, Group 1 consisted of those who reportedly practice Buddhism, whereas Group 2 comprised of non-religious language learners.

The participants of Group 1 (Table 1) are the Buddhist representatives of Kalmykia, Tuva, and Buryatia, which are Russia's traditionally Buddhist republics (Badmaev et al., 2020) and mostly the eponymous representatives of the designated regions. All of them are born and/or reside in Kalmykia.

At the time of the experiment, the representatives of both groups were studying for their undergraduate $(n=15)$, graduate $(n=4)$, and postgraduate degree $(n=1)$ at Kalmyk State University named after B. B. Gorodovikov.

Both groups reported roughly the same proficiency level of English, that is, intermediate. Their first language (L1) backgrounds are either Russian or/and Kalmyk, or Russian or/and Tuvan, Russian or/and Buryat, respectively. However, the majority of participants acknowledged that Russian is the dominant language in their daily communication. They all reported normal or corrected-to-normal vision and no neurological disorders. 
Table 1. The demographic data for Group 1.

\begin{tabular}{|c|c|c|c|c|c|c|}
\hline ID & Birthplace & Sex & Age & Occupation & Major & L1 \\
\hline 1 & Kalmykia & F & 19 & Bachelor's student & Chemistry & Russian, Kalmyk \\
\hline 3 & Kalmykia & M & 20 & Bachelor's student & Chemistry & Russian \\
\hline 4 & Buryatia & F & 18 & Bachelor's student & Mathematics & Russian, Buryat \\
\hline 5 & Kalmykia & F & 19 & Bachelor's student & Pharmacy & Russian, Kalmyk \\
\hline 7 & Kalmykia & F & 20 & Bachelor's student & Kalmyk Studies & Russian, Kalmyk \\
\hline 9 & Kalmykia & F & 20 & Bachelor's student & Biology & Russian \\
\hline 10 & Kalmykia & F & 20 & Bachelor's student & Psychology & Russian, Kalmyk \\
\hline 13 & Tuva & F & 20 & Bachelor's student & Life safety & Russian, Tuvan \\
\hline 14 & Tuva & M & 24 & Master's student & Construction & Russian, Tuvan \\
\hline 17 & Kalmykia & F & 21 & Bachelor's student & Psychology & Russian \\
\hline
\end{tabular}

The participants of Group 2 (Table 2) are born and reside in Kalmykia and reportedly do not practice Buddhism and do not affiliate themselves with any other spiritual practices or religions.

Table 2. The demographic data for Group 2.

\begin{tabular}{|c|c|c|c|c|c|c|}
\hline ID & Birthplace & Sex & Age & Occupation & Major & L1 \\
\hline 2 & Kalmykia & M & 21 & Bachelor's student & Physics & Russian \\
\hline 6 & Kalmykia & M & 19 & Bachelor's student & Veterinary & Russian, Kalmyk \\
\hline 8 & Kalmykia & F & 20 & Bachelor's student & Biology & Russian, Kalmyk \\
\hline 11 & Kalmykia & F & 38 & Postgraduate student & Pedagogy & Russian \\
\hline 12 & Kalmykia & M & 25 & Master's student & Zootechnics & Russian \\
\hline 15 & Kalmykia & M & 24 & Master's student & Law & Russian \\
\hline 16 & Kalmykia & F & 23 & Master's student & Law & Russian, Kalmyk \\
\hline 18 & Kalmykia & F & 21 & Bachelor's student & Psychology & Russian \\
\hline 19 & Kalmykia & F & 21 & Bachelor's student & Psychology & Russian \\
\hline 20 & Kalmykia & M & 20 & Bachelor's student & Psychology & Russian \\
\hline
\end{tabular}

\section{Material and method}

The study took the form of the self-paced reading task (Marinis, 2010). The name of the task itself is attributable to the manner how parsers read stimulus and regulate its presentation pace. They are typically invited to read word chunks or whole sentences by pressing a specified key. In the background, each key press is automatically documented with the objective to furnish quantitative insights into stimuli processing. Longer processing times are considered to reveal difficulties in the course of processing (Roberts, Liszka, 2013).

Pertinent to this study, non-cumulative word-by-word (White, Palmer, Boynton, 2020) manner of presentation was opted for owing to its resemblance to natural reading. The Ibex Farm platform, ver. 0.39 ${ }^{1}$ was used for designing and hosting the Internet-based experiment.

As the study controls for the effect of English proficiency, it was critical to compose the English-medium texts that are adequate for intermediate proficiency in the target language. Accordingly, the study generated the two short texts, with the length of 52 words each. Based on the Flesch Reading Ease formula (Crossley, Greenfield, McNamara, 2008), the mean score of 88.5 was computed, signaling about the reading suitability of texts for intermediate learners.

${ }^{1}$ Drummond, A., von der Malsburg, T., Erlewine, M. Y., Yoshida, F. and Vafaie, M. (2016) Ibex farm. https://github.com/ addrummond/ibex. GitHub 
In terms of the thematic area, one of the texts was related to Buddhism, while the other was about recycling, therefore, religiously neutral. The custom-made web-based script collected RT per each word of both texts and gathered metalinguistic data at the stage of post-processing.

Prior to the experiment, following the existing recall summary protocols (Alderson, 2000; Riley, Lee, 1996), the total number of idea units per each text was determined. Every new content word or phrase was regarded as a single idea unit. So, the Buddhism-related text had four units or pieces of new information in its first sentence, as well as three and five idea units in the second and third sentences, respectively. The first sentence of the religiously neutral text consisted of four idea units, whereas five and three units were found in the second and third sentences, respectively. Overall, each text had 12 idea units.

The obtained recall summaries were therefore broken down into idea units and then matched with the content of both texts to ascertain whether the summaries were accurate and give inasmuch as the information from the texts.

\section{Procedure}

Due to COVID-19, the participants took part in the study remotely, at the place of their residence. They were requested to be seated in front of their laptop or desktop computers at a comfortable chair and in a welllit area.

Before the actual task, the on-screen message was appearing (Figure 6) to inform the participants about the experimental procedure. They were notified that their involvement is voluntary and their withdrawal from the experiment at any stage cannot impinge negatively upon them. To secure confidentiality of the results, the participants inserted only their unique identification number (ID), which was given by the investigator prior to the experiment, in the same window as well as provided their informed consent.

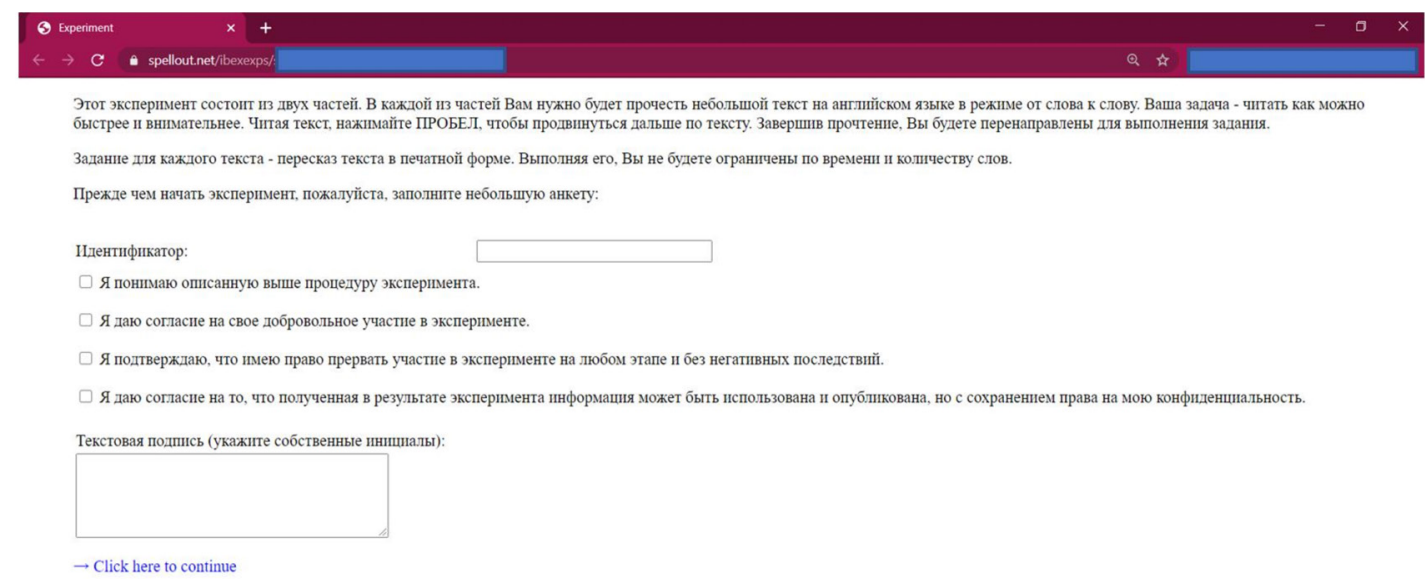

Figure 5. The welcome page that includes information about the experimental procedure and collects an informed consent.

The task of the participants was to read the two short texts one after the other. Each text was separated into three sentences, whereas each sentence was displayed word-by-word on a separate screen at a non-cumulative fashion (Figure 7). At the initial stage, the sentences were introduced in the form of dashes. Pressing the space key was triggering the first word to appear instead of dashes, whereas the next space keypresses made the first word to revert into dashes and opened the next word accordingly.

Upon the end of each text's reading and in a separate page window, the participants were required to type-in their recall summary of what they have just read. This protocol has been regarded (Bernhardt, 1983) as the measure for assessing language learner's reading competence by targeting at the interface between the stimulus and the reader. The participants were confined to the use of any external help (e. g., Internet, friends, etc.) and were time-unrestricted and had no word limit. RTs per each word and typed-in free recall summaries were coded and stored for further analyses.

After the task completion, the participants were invited to fill out the brief questionnaire for the purpose of demographic data collection. The entire experiment, including the time spent for taking informed consent and questionnaire, lasted roughly 15 minutes. 


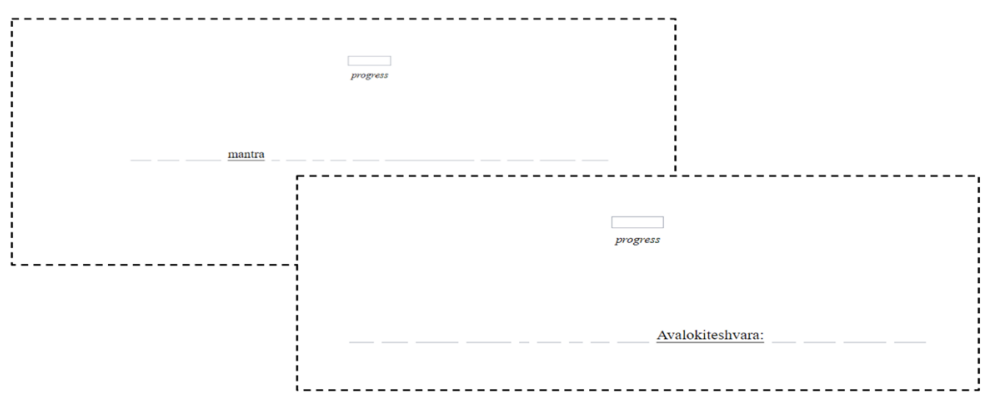

Figure 6. The example of the non-cumulative and word-by-word stimuli presentation through Ibex. It particularly demonstrates the fourth and tenth words of the second sentence of the Buddhist-related text.

\section{Results}

The aggregate number of idea units elicited correctly and overall RTs per each text were the dependent variables of the study.

The obtained data was filtered according to the filtering criteria (Prasad, Linzen, 2019). In the questionnaire, one of the participants stated that German is their target language and not English, despite the fact that all the potential participants were informed about the prerequisite to have English as a target language so as to be eligible for the study. The trial number 15 was therefore excluded from further analyses.

All trials were then checked for any length effect, so that if RT per word was longer than 2000 milliseconds $(\mathrm{ms})$, they had to be excluded. This was not relevant to any of the participants. After the preliminary check of typed-in recall summaries, the trial number 2 , in which the participant did not put any recall summaries, was excluded. These instances led to the elimination of $10 \%$ of trials, totaling the trials for analyses to 18 (Tables 3 and 4). Both of these trials were from Group 2.

Table 3. The overall reading time ( $\left.B_{-} R T s ; N_{-} R T s\right)$ and the cumulative number of idea units $\left(B_{-} U ; N_{-} U\right)$ per each text for Group 1

\begin{tabular}{|c|c|c|c|c|}
\hline$I D$ & B_RTs & $N \_R T s$ & $B_{-} U$ & $N_{-} U$ \\
\hline 1 & 11342 & 12543 & 10 & 9 \\
\hline 3 & 12894 & 13063 & 8 & 8 \\
\hline 4 & 11584 & 12329 & 9 & 5 \\
\hline 5 & 14089 & 14876 & 6 & 5 \\
\hline 7 & 11201 & 11458 & 12 & 10 \\
\hline 9 & 12544 & 14235 & 11 & 8 \\
\hline 10 & 11097 & 11802 & 10 & 7 \\
\hline 13 & 12045 & 12784 & 11 & 9 \\
\hline 14 & 13611 & 15328 & 9 & 7 \\
\hline 17 & 15326 & 15122 & 8 & 5 \\
\hline Mean & 12573.3 & 13354 & 9.4 & 7.3 \\
\hline
\end{tabular}


НОВЫЕ ИССЛЕДОВАНИЯ ТУВЫ

www.nit.tuva.asia
THE NEW RESEARCH OF TUVA

2021
Novye issledovaniia Tuvy

Table 4. The overall reading time (B_RTs; $\left.N_{-} R T s\right)$ and the cumulative number of idea units $\left(B_{-} U ; N_{-} U\right)$

\begin{tabular}{|c|c|c|c|c|}
\hline$I D$ & $B_{-} R T S$ & $N_{-} R T S$ & $B_{-} U$ & $N_{-} U$ \\
\hline 6 & 14872 & 13213 & 7 & 8 \\
\hline 8 & 13298 & 14983 & 8 & 9 \\
\hline 11 & 15982 & 15022 & 4 & 7 \\
\hline 12 & 16384 & 15991 & 6 & 8 \\
\hline 16 & 13004 & 12537 & 8 & 6 \\
\hline 18 & 16091 & 14302 & 3 & 6 \\
\hline 19 & 15487 & 13871 & 4 & 7.25 \\
\hline 20 & 14786 & 13039 & 6 & $\mathbf{5 . 7 5}$ \\
\hline \multirow{2}{*}{ Mean } & $\mathbf{1 4 9 8 8}$ & $\mathbf{1 4 1 1 9 . 7 5}$ & & \\
\hline
\end{tabular}

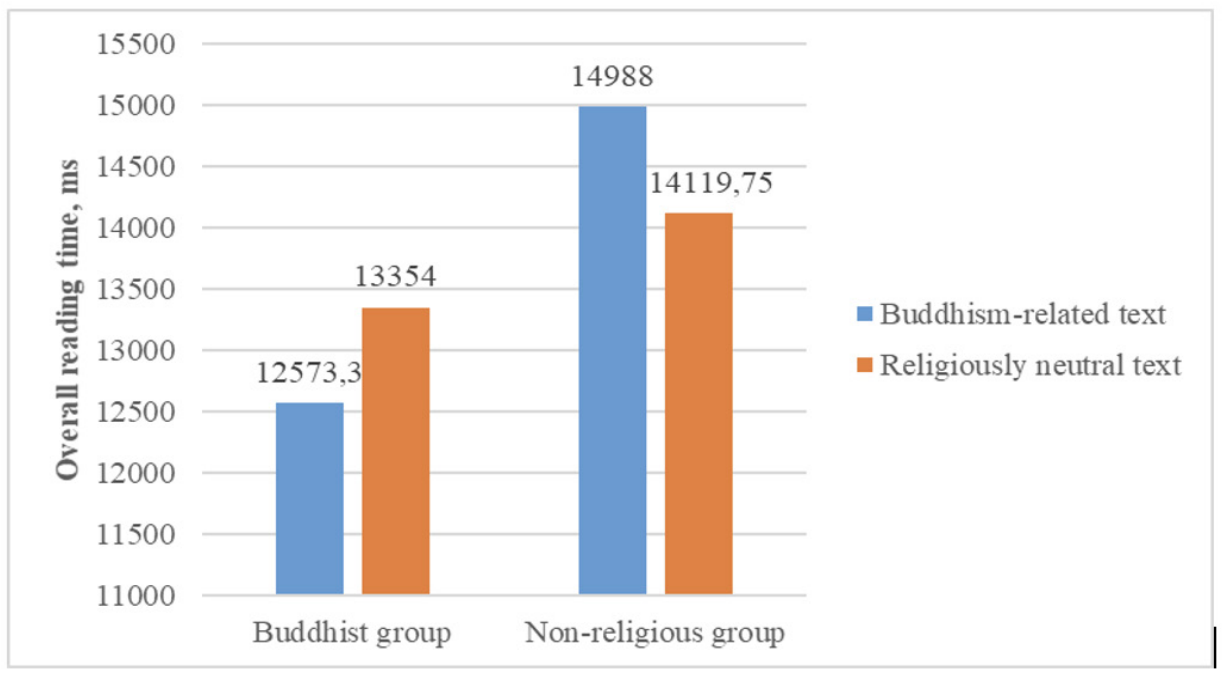

Figure 7. The overall reading times in milliseconds per each text of both groups.

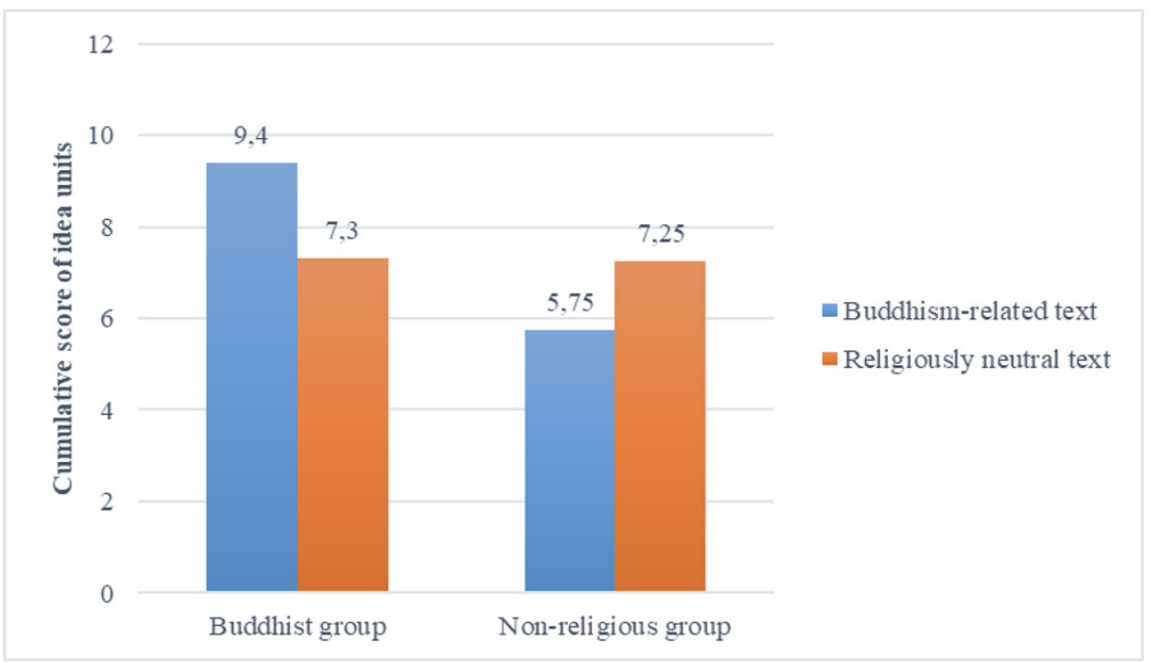

Figure 8. The cumulative recall summary scores per each text of both groups. 
Based on Figure 8, Group 1 processed the Buddhism-related text more rapidly than Group 2, $12573.3 \mathrm{~ms}$ vs. $14988 \mathrm{~ms}$ respectively. The text with no reference to religions was read faster by Group 1 than the participants from Group 2, $13354 \mathrm{~ms}$ vs. $14119.75 \mathrm{~ms}$. So, Group 2 performed somewhat contrary to anticipations because it actually did worse on the religiously neutral text than Group 1. In sum, for each text's processing, Group 2 spent more time than the counterparts from Group 1.

As observed from Figure 9, Group 1 generated higher number of idea units than the second one after reading of Buddhism-related short text in English, 9.4 vs. 5.75, respectively. Notably, one of the participants from Group 1 managed to recall the Buddhism-related text verbatim. As of the religiously neutral text, both groups showed quite similar results in their post-processing recall, 7.3 vs 7.25.

\section{Discussion and conclusion}

The results of the small-scale study clearly indicate that religious background of language learners has a considerable influence on the real-time processing and its further recall. Particularly, it reduces the processing load and therefore makes the reading material in the target language easier to process and remember.

Remarkably, Buddhism-affiliated language learners with intermediate English performed just as well in the processing of Buddhism-related and religiously neutral texts. The number of idea units is higher in Group 1 than Group 2, again, owing to the knowledge from their religious background. Perhaps, one way to interpret this result is that spiritually close texts are in general remembered well and retrieved from memory better owing to the fact that they introduce the ideas, facts, and information from the native spiritual background or tradition.

The non-religious group experienced processing difficulties while reading both religiously neutral and Buddhism-related texts. These findings would be justified by the two possible explanations. This group was either not homogenous in language proficiency or did not produce rigid results merely because of the small sample size as it eventually had contributed less trials for analyses due to data filtering. Regarding the number of idea units, the participants with no religious affiliation managed to recall the processed text quite well, but slightly worse than the Buddhist counterparts. Once again, this result would either suggest that the proficiency level of the target language was inconsistent within the group, or the group did not provide stable results due to filtering.

Based on these findings, the study posits that the Buddhist background of non-native readers is a contributing factor to faster processing of Buddhist-specific texts in the target language and their better recall. The obtained results may generalize that the usefulness of knowledge from religious background leads to faster and better understanding of religiously related written material in a target language.

The findings of the conducted study also inform language pedagogy with regard to the mindfulness of the interface arising between the learner's background and the text. Educators may need to focus on the use of it to the learner's benefit, thus, enhance their student's language acquisition. Likewise, language instructors need to be conscious of the efficacy of providing supplementary resources such as notes and glossary to augment processing and recall of texts related to religion in atheist and religiously neutral language learners.

\section{REFERENCES}

Alderson, J. (2000) Assessing Reading (Cambridge Language Assessment). Cambridge, Cambridge University Press. DOI: https://doi.org/10.1017/CBO9780511732935

An, S. (2013) Schema Theory in Reading. Theory \& Practice in Language Studies, 3(1). DOI: https://doi.org/10.4304/ TPLS.3.1.130-134

Badmaev, V. N., Ulanov, M. S., Lamazhaa, Ch. K., Bicheldey, U. N., Antonov, V. I. and Ochirova, O. A. (2020) Russia and the Buddhist world through the eyes of the youth in Tuva, Buryatia, and Kalmykia: a sociological survey and its outcomes. New Research of Tuva, no. 1, pp. 36-49. DOI: https://doi.org/10.25178/nit.2020.1.3

Bernhardt, E. B. (1983) Three approaches to reading comprehension in intermediate German. The Modern Language Journal, no. 67(2), pp. 111-115. DOI: https://doi.org/10.1111/j.1540-4781.1983.tb01478.x

Carreiras, M., Armstrong, B. C., Perea, M. and Frost, R. (2014) The what, when, where, and how of visual word recognition. Trends in Cognitive Sciences, no. 18(2), pp. 90-98. DOI: https://doi.org/10.1016/j.tics.2013.11.005

Crossley, S. A., Greenfield, J. and McNamara, D. S. (2008) Assessing text readability using cognitively based indices. TESOL Quarterly, no. 42(3), pp. 475-493. DOI: https://doi.org/10.1002/j.1545-7249.2008.tb00142.x 
Delgado, P. and Salmerón, L. (2021) The inattentive on-screen reading: Reading medium affects attention and reading comprehension under time pressure. Learning and instruction, no. 71. DOI: https://doi.org/10.1016\%2Fj. learninstruc.2020.101396

Dell, G. S. and Chang, F. (2014) The P-chain: Relating sentence production and its disorders to comprehension and acquisition. Philosophical Transactions of the Royal Society B: Biological Sciences, no. 369(1634). DOI: https://doi. org/10.1098/rstb.2012.0394

Ferreira, F. and Chantavarin, S. (2018) Integration and prediction in language processing: A synthesis of old and new. Current Directions in Psychological Science, no. 27(6), pp.443-448. DOI: https://doi.org/10.1177\%2F0963721418794491

Graesser, A. C., Singer, M. and Trabasso, T. (1994) Constructing inferences during narrative text comprehension. Psychological Review, no. 101(3). DOI: https://doi.org/10.1037/0033-295X.101.3.371

Henry, N. A. (2015) Morphosyntactic processing, cue interaction, and the effects of instruction: An investigation of processing instruction and the acquisition of case markings in L2 German. Doctoral dissertation. Pennsylvania State University.

Kekeeva, Z., Darzhinova, S. and Abdiraimova, E. (2020) Development of the reading culture in pre-service teachers amid digitalization of education. In: E3S Web of Conferences (Vol. 210, p. 18083). EDP Sciences. DOI: https://doi.org/10.1051/ e3sconf/202021018083

Kuperberg, G. R. and Jaeger, T. F. (2016) What do we mean by prediction in language comprehension? Language, Cognition and Neuroscience, no. 31(1), pp. 32-59. DOI: https://doi.org/10.1080/23273798.2015.1102299

Long, D. L. and Lea, R. B. (2005) Have we been searching for meaning in all the wrong places? Defining the "search after meaning” principle in comprehension. Discourse processes, no. 39(2-3), pp. 279-298. DOI: https://doi.org/10.1207/ s15326950dp3902\&3_10

Marinis, T. (2010) Using on-line processing methods in language acquisition research. In: Unsworth, S. and Blom, E. (Eds.) Experimental Methods in Language Acquisition Research. Amsterdam, John Benjamins Publishing Company. 292 p. Pp. 139-162. DOI: https://doi.org/10.1075/1llt.27.09mar

Markham, P. (2001) The influence of culture-specific background knowledge and captions on second language comprehension. Journal of Educational Technology Systems, no. 29(4), pp. 331-343. https://doi.org/10.2190/15TA-GX8P74XP-YUA1

Murray, J. D., Klin, C. M. and Myers, J. L. (1993) Forward inferences in narrative text. Journal of Memory and Language, no. 32(4), pp. 464-473. DOI: https://doi.org/10.1006/jmla.1993.1025

Navracsics, J. and Darzhinova, L. (2020) The Use of PsychToolbox-3 for Tracking Bilingual Sentence Processing and Comprehension. In: CEUR Workshop Proceedings. Aachen, RWTH Aachen University Publishing. Vol. 2780, Pp. $123-131$.

Nilsson, P. (2015) A Snowball Sampling Approach for Studying Digital Minority Languages. Doctoral dissertation. Swarthmore College.

Prasad, G. and Linzen, T. (2019) Do self-paced reading studies provide evidence for rapid syntactic adaptation. Prepr. PsyArXiv. DOI: https://doi.org/10.31234/osf.io/9ptg4

Riley, G. L. and Lee, J. F. (1996) A comparison of recall and summary protocols as measures of second language reading comprehension. Language testing, no. 13(2), pp. 173-189. DOI: https://doi.org/10.1177\%2F026553229601300203

Roberts, L. and Liszka, S. A. (2013) Processing tense/aspect-agreement violations on-line in the second language: A self-paced reading study with French and German L2 learners of English. Second Language Research, no. 29(4), pp. 413-439. DOI: https://doi.org/10.1177/0267658313503171

Rumelhart, D. (1980) Schemata: The Building Blocks of Cognition. In: Spiro, R., Bruce, B. and Brewer, W., Eds. Theoretical Issues in Reading Comprehension, Erlbaum Associates, Mahway. Pp. 33-58. DOI: https://doi.org/10.4324/9781315107493

Smith, N. J. and Levy, R. (2013) The effect of word predictability on reading time is logarithmic. Cognition, no. 128(3), pp. 302-319. DOI: https://doi.org/10.1016/j.cognition.2013.02.013

Veldre, A. and Andrews, S. (2018) Beyond cloze probability: Parafoveal processing of semantic and syntactic information during reading. Journal of Memory and Language, 100, pp. 1-17. DOI: https://doi.org/10.1016/j.jml.2017.12.002

White, A. L., Palmer, J. and Boynton, G. M. (2020) Visual word recognition: Evidence for a serial bottleneck in lexical access. Attention, Perception, \& Psychophysics, no. 82(4), pp. 2000-2017. DOI: https://doi.org/10.3758/s13414-019-01916-Z

Submission date: 02.02.2021. 